\title{
1,3-Butanediol Dibenzoate
}

\author{
Wataru Hakamata *, Kaho Goto, Sakiko Ishiwata, Rieka Ouki, Riku Sakai, Arisa Iizuka, \\ Shuta Yano, Takako Hirano and Toshiyuki Nishio
}

\author{
Department of Chemistry and Life Science, College of Bioresource Sciences, Nihon University, 1866 Kameino, \\ Fujisawa-shi, Kanagawa 252-0880, Japan; kah.021-t.t.c@hotmail.co.jp (K.G.); sacchan-v_v-i@i.softbank.jp (S.I.); \\ dr-eam.ba-ba.s52s@ezweb.ne.jp (R.O.); riku.sakai.0526@gmail.com (R.S.); l-v-lari@softbank.ne.jp (A.I.); \\ shuta02_8no21_invaded@yahoo.co.jp (S.Y.); hirano.takako@nihon-u.ac.jp (T.H.); \\ nishio.toshiyuki@nihon-u.ac.jp (T.N.) \\ * Correspondence: hakamata.wataru@nihon-u.ac.jp; Tel.: +81-46-684-3960
}

Academic Editor: Norbert Haider

Received: 16 July 2016; Accepted: 12 August 2016; Published: 17 August 2016

\begin{abstract}
Environmentally friendly and straightforward methods for creating biofuels are required to promote biofuel use. Therefore, we present here a convenient and environmentally friendly direct self-aldol reaction of acetaldehyde in $100 \mathrm{mM}$ borate buffer ( $\mathrm{pH} 10)$ affording the dimer of 3-hydroxybutanal with a good yield. The product can be easily converted into 1,3-butanediol and its benzoate; therefore, our results will have a positive impact in the field of biochemical production from ethanol.
\end{abstract}

Keywords: self-aldol reaction; acetaldehyde; environment-friendly reaction; biorefinery; bioethanol

\section{Introduction}

A biorefinery is a system in which renewable biomass substances are converted to bio-based products. The system is now the focus of worldwide attention as an alternative to the oil refinery system. High and volatile oil prices, coupled with increasing $\mathrm{CO}_{2}$ concentrations in the atmosphere causing the greenhouse effect, has been an important social catalyst in organic chemistry to produce bio-based products using biomass as the starting material with environmentally friendly reactions [1-3]. In developed countries, most governments are prioritizing research on bioethanol as well as the development of a bioethanol industry, in particular for fuel purposes. Previous studies on practical bioethanol production had shown that the cost of producing bioethanol was surprisingly high and that reducing this cost was key to making bioethanol economically viable. Subsequently, a lot of effort was expended on increasing the cost effectiveness of producing bioethanol, and the cost of bioethanol has been dramatically reduced [4-6].

We therefore tried using bioethanol as a starting material in an environmentally friendly synthesis reaction to obtain 1,3-butanediol (2), which is used in large quantities and is a very important industrial raw material [7,8]. 1,3-Butanediol (2) can be synthesized from ethanol using the following steps: Step (1) an ethanol molecule is oxidized to an acetaldehyde; Step (2) the acetaldehyde molecule provides 3-hydroxybutanal via a direct self-aldol reaction; and Step (3) 1,3-butanediol (2) is obtained by reduction of 3-hydroxybutanal. However, the direct self-aldol reaction of acetaldehyde in Step 2 is difficult because the generated aldehyde acts both as a reactive electrophile and as a nucleophile, causing overreactions. In this paper, we describe the first successful realization of the direct self-aldol reaction of acetaldehyde under environmentally friendly reaction conditions, i.e., catalyst free and using water as the reaction media. 


\section{Results and Discussion}

In the direct self-aldol reaction of acetaldehyde, the high reactivity of 3-hydroxybutanal, which can act as both an electrophile and a nucleophile, becomes a problem [9-13]. To solve this problem, the hydroxyl and aldehyde groups of 3-hydroxybutanal are reacted and converted into an acetal. In other words, an acetal dimerization of 3-hydroxybutanal is carried out to simultaneously mask the reactivity of the hydroxyl and aldehyde groups. Furthermore, this should be achieved using environmentally friendly reaction conditions, for example, using water as the reaction solvent. To achieve a direct self-aldol reaction of acetaldehyde and immediate subsequent dimerization of the aldol product, a two-step reaction from acetaldehyde was examined, focusing on the variety of combinations of conditions such as the $\mathrm{pH}$ of reaction media, acetaldehyde concentration, reaction time, and reaction temperature.

The results are summarized in Tables 1 and 2. The best result of the two-step reaction (direct self-aldol reaction of acetaldehyde and dimerization reaction) in water was obtained when $5 \mathrm{M}$ acetaldehyde in $100 \mathrm{mM}$ Na borate buffer, $\mathrm{pH}$ 10, and a $48 \mathrm{~h}$ reaction at ambient temperature were employed to afford compound 1 with a $69 \%$ yield (Table 1, Entry 4 and Table 2, Entry 7).

Table 1. Optimizing the direct self-aldol reaction and dimerization reaction conditions under $\mathrm{pH} 7$ to 10 using $5 \mathrm{M}$ acetaldehyde.

\begin{tabular}{ccc}
\hline Entry & Reaction Condition & Isolated Yield of $\mathbf{1}$ \\
\hline 1 & $100 \mathrm{mM}$ Na phosphate buffer, $\mathrm{pH} 7$ & not detected \\
2 & $100 \mathrm{mM}$ Na phosphate buffer, $\mathrm{pH} 8$ & trace \\
3 & $100 \mathrm{mM}$ Na borate buffer, $\mathrm{pH} 9$ & $25 \%$ \\
4 & $100 \mathrm{mM} \mathrm{Na}$ borate buffer, $\mathrm{pH} 10^{\mathrm{m}}$ & $69 \%$ \\
5 & $100 \mathrm{mM} \mathrm{Na}_{2} \mathrm{HPO}_{4}-\mathrm{NaOH}$ buffer, $\mathrm{pH} \mathrm{11}$ & $31 \%$ \\
\hline
\end{tabular}

Table 2. Optimizing the direct self-aldol reaction and dimerization reaction conditions under different acetaldehyde concentrations and reaction time at $\mathrm{pH} 10$.

\begin{tabular}{cccc}
\hline Entry & Concentration (M) & Reaction Time (h) & Isolated Yield of $\mathbf{1}$ \\
\hline 1 & 0.5 & 48 & $35 \%$ \\
2 & 1.0 & 48 & $43 \%$ \\
3 & 2.0 & 48 & $49 \%$ \\
4 & 3.0 & 48 & $61 \%$ \\
5 & 4.0 & 48 & $67 \%$ \\
6 & 5.0 & 24 & $54 \%$ \\
7 & 5.0 & 48 & $69 \%$ \\
8 & 5.0 & 72 & $62 \%$ \\
\hline
\end{tabular}

We were able to isolate compound $\mathbf{1}$ with good yield, as compound $\mathbf{1}$ is relatively stable on silica gel. The NMR and MS of compound $\mathbf{1}$ suggested that dimer was the main product. Compound $\mathbf{1}$ was reduced to 1,3-butanediol using $\mathrm{NaBH}_{4}$ in $\mathrm{MeOH}$, and then the product was benzoylated. The isolated yield of benzoylated product 3 synthesized in two steps was determined to be $81 \%$. The reaction scheme is summarized in Scheme 1.

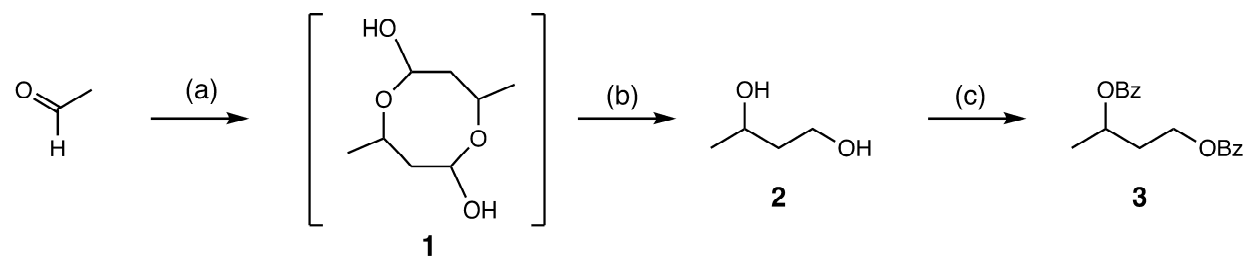

Scheme 1. Synthesis of 1,3-butanediol dibenzoate (3). Reagents and conditions: (a) $100 \mathrm{mM}$ borate buffer $\mathrm{pH} 10$, ambient temperature, 2 days, with yield of $69 \%$; (b) $\mathrm{NaBH}_{4}, \mathrm{MeOH}, 0{ }^{\circ} \mathrm{C}, 1 \mathrm{~h}$; (c) $\mathrm{PhCOCl}$, $\mathrm{Et}_{3} \mathrm{~N}$, DMAP, $\mathrm{CH}_{2} \mathrm{Cl}_{2}$, ambient temperature, $18 \mathrm{~h}$, with yield of $81 \%$ (2 steps). 
We conducted a high-performance liquid chromatography (HPLC) analysis of the compounds $\mathbf{3 R}$ and $3 S$. The compound $\mathbf{2} R$ was benzoylated according to the conventional method (Scheme 2). Retention times of $3 R$ and $3 S$ were determined by the HPLC condition using synthesized racemic 3 and $3 R$. The retention times of $3 R$ and $3 S$ were $14.8 \mathrm{~min}$ and $22.0 \mathrm{~min}$, respectively. In the future, it is important to develop asymmetric and catalytic versions of the direct self-aldol reaction of acetaldehyde in water media [10].

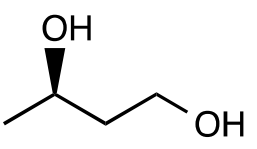

$2 R$

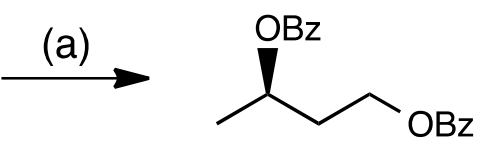

$3 R$

Scheme 2. Synthesis of (R)-1,3-butanediol dibenzoate (3R). Reagents and conditions: (a) PhCOCl, $\mathrm{Et}_{3} \mathrm{~N}$, DMAP, $\mathrm{CH}_{2} \mathrm{Cl}_{2}, 18 \mathrm{~h}$, ambient temperature, with yield of $83 \%$.

Sustainable production of chemicals remains essential both commercially and scientifically. 1,3-Butanediol has gained significant attention as an important commodity chemical with broad applications. Bioethanol can be converted to 1,3-butanediol without the use of a catalyst in water through a self-aldol reaction of acetaldehyde. The experimental results demonstrate that the acetaldehyde concentrations and $\mathrm{pH}$ of water were particularly important for the desired self-aldol reaction. All these results indicate the promising application of the developed self-aldol reaction of acetaldehyde in producing useful biochemicals from bioethanol.

\section{Experimental Section}

\subsection{General Information}

The ${ }^{1} \mathrm{H}$ spectra of the compounds were recorded on an ECA500 spectrometer (JEOL, Tokyo, Japan) after the compounds were dissolved in $\mathrm{CDCl}_{3}$; Tetramethylsilane was used as an internal standard. The coupling constants $(J)$ are reported in $\mathrm{Hz}$ and refer to the apparent peak multiplicities ( $\mathrm{s}=$ singlet, $\mathrm{d}=$ doublet, $\mathrm{dd}=$ double doublet, $\mathrm{ddd}=$ triple doublet, $\mathrm{m}=$ multiple). Low-resolution mass spectra were obtained with a Quattro Premier XE instrument (Waters, Milford, MA, USA) under positive and negative ion electrospray ionization conditions. Column chromatography was performed using Silica Gel 60N with a spherical neutral particle size of 100-210 $\mu \mathrm{m}$ (Kanto Chemical, Tokyo, Japan). The progress of all reactions was monitored by thin-layer chromatography on Silica Gel $60 \mathrm{~F}_{254}$ $0.25 \mathrm{~mm}$ (E. Merck, Darmstadt, Germany). Optical rotations were measured with a P-1020 polarimeter (JASCO, Tokyo, Japan) at $25^{\circ} \mathrm{C}$. HPLC was performed on a Hitachi LaChrom Elite system by Hitachi High Technologies Inc., Tokyo, Japan (UV detector: L-2400; pump: L-2130; column oven: L-2300 $\left(30{ }^{\circ} \mathrm{C}\right)$; column: CHIRALCEL OD-H (4.6 mm $\times 250 \mathrm{~mm}$, DAICEL, Tokyo, Japan); isocratic eluent: hexane/2-propanol 93:7; flow rate $=1.0 \mathrm{~mL} / \mathrm{min}$; wavelength: $240 \mathrm{~nm}$; and overall run time: $40 \mathrm{~min}$ ).

\subsection{Synthesis of 1,3-Butanediol Dibenzoate (3) from Acetaldehyde}

To make $25 \mathrm{~mL}$ of $5 \mathrm{M}$ acetaldehyde solution, $5.5 \mathrm{~g}$ of freshly prepared acetaldehyde Sigma-Aldrich (St. Louis, MI, USA, 00070-100ML) was dissolved in $100 \mathrm{mM}$ sodium borate buffer (pH 10), fill up to $25 \mathrm{~mL}$. The $25 \mathrm{~mL}$ of $5 \mathrm{M}$ acetaldehyde solution was stirred at ambient temperature for 2 days. The reaction mixture was poured into ethyl acetate and the product was extracted three times with ethyl acetate. The organic layer was dried over $\mathrm{Na}_{2} \mathrm{SO}_{4}$ and then evaporated. The obtained residue was purified by column chromatography on silica gel (1:1, hexane:ethyl acetate) to afford $3.78 \mathrm{~g}$ (69\% yield) of 3-hydroxybutanal dimer (1).

To a stirred solution of freshly purified 3-hydroxybutanal dimer (203 mg, $1.15 \mathrm{mmol})$ in $\mathrm{MeOH}$ $(5 \mathrm{~mL}), \mathrm{NaBH}_{4}\left(143.3 \mathrm{mg}, 3.11 \mathrm{mmol}\right.$, assay 90\%) was added at $0{ }^{\circ} \mathrm{C}$. The stirring was continued at 
this temperature for $1 \mathrm{~h}$. Afterwards, the reaction mixture was directly processed using column chromatography on silica gel (25:1, diethylether:hexane) to furnish the reduced product, which consisted mainly of compound 2. This product was diluted with dry $\mathrm{CH}_{2} \mathrm{Cl}_{2}(10 \mathrm{~mL})$ and $\mathrm{Et}_{3} \mathrm{~N}$ $(860 \mu \mathrm{L}, 6.18 \mathrm{mmol}), \mathrm{DMAP}(113.7 \mathrm{mg}, 0.93 \mathrm{mmol})$, and PhCOCl $(540 \mu \mathrm{L}, 4.64 \mathrm{mmol})$ were added to it at $4{ }^{\circ} \mathrm{C}$, and the solution was stirred for $18 \mathrm{~h}$. Subsequently, the reaction mixture was quenched with $1 \mathrm{M} \mathrm{HCl}(50 \mathrm{~mL})$, extracted with ethyl acetate $(50 \mathrm{~mL})$, and washed with saturated $\mathrm{NaHCO}_{3}$ and brine. The organic layer was dried over $\mathrm{Na}_{2} \mathrm{SO}_{4}$ and then evaporated. The residue obtained was purified by column chromatography on silica gel (5:1, hexane:ethyl acetate) to afford $557.5 \mathrm{mg}$ (1.87 mmol, $81 \%$ Yield) of 1,3-butanediol dibenzoate (3), see Figures S2 and S4 for more information.

${ }^{1} \mathrm{H}-\mathrm{NMR}\left(500 \mathrm{MHz}, \mathrm{CDCl}_{3}\right): \delta 1.45(\mathrm{~d}, 3 \mathrm{H}, J=6.5 \mathrm{~Hz}), 2.12-2.26(\mathrm{~m}, 2 \mathrm{H}), 4.42(\mathrm{ddd}, 1 \mathrm{H}, J=4.9 \mathrm{~Hz}$, $J=6.6 \mathrm{~Hz}, J=13 \mathrm{~Hz}), 4.50(\mathrm{dd}, 1 \mathrm{H}, J=5.8 \mathrm{~Hz}, J=11.5 \mathrm{~Hz}), 5.40(\mathrm{~m}, 1 \mathrm{H})$, and 7.41-8.04 $(\mathrm{m}, 10 \mathrm{H})$. ESI-MS (Positive mode); $m / z=321[\mathrm{M}+\mathrm{Na}]^{+}$. Spectroscopic data for characterization can be found in reference [10].

\subsection{Synthesis of (R)-1,3-Butanediol Dibenzoate (3R)}

To (R)-1,3-butanediol (2R, $100 \mathrm{mg}, 1.11 \mathrm{mmol}$, Tokyo Chemical Industry, Tokyo, Japan) in dry $\mathrm{CH}_{2} \mathrm{Cl}_{2}(10 \mathrm{~mL}), \mathrm{Et}_{3} \mathrm{~N}(619 \mu \mathrm{L}, 4.44 \mathrm{mmol}), \mathrm{DMAP}(81.4 \mathrm{mg}, 0.66 \mathrm{mmol})$, and PhCOCl $(387 \mu \mathrm{L}$, $3.33 \mathrm{mmol}$ ) were added at $4{ }^{\circ} \mathrm{C}$, and the solution was stirred for $18 \mathrm{~h}$. After that, the reaction mixture was quenched with $1 \mathrm{M} \mathrm{HCl}(50 \mathrm{~mL})$, extracted with ethyl acetate $(50 \mathrm{~mL})$, and washed with saturated $\mathrm{NaHCO}_{3}$ and brine. The organic layer was dried over $\mathrm{Na}_{2} \mathrm{SO}_{4}$ and then evaporated. The residue obtained was purified by column chromatography on silica gel (5:1, hexane:ethyl acetate) to afford $293.3 \mathrm{mg}$ ( $0.75 \mathrm{mmol}, 83 \%$ yield) of ( $R$ )-1,3-butanediol dibenzoate (3R), see Figures S1 and S3 for more information.

${ }^{1} \mathrm{H}-\mathrm{NMR}\left(500 \mathrm{MHz}, \mathrm{CDCl}_{3}\right): \delta 1.45(\mathrm{~d}, 3 \mathrm{H}, J=6.5 \mathrm{~Hz}), 2.12-2.26(\mathrm{~m}, 2 \mathrm{H}), 4.42(\mathrm{ddd}, 1 \mathrm{H}, J=4.6 \mathrm{~Hz}$, $J=6.6 \mathrm{~Hz}, J=13.3 \mathrm{~Hz}), 4.50(\mathrm{dd}, 1 \mathrm{H}, J=5.6 \mathrm{~Hz}, J=11.3 \mathrm{~Hz}), 5.40(\mathrm{~m}, 1 \mathrm{H})$, and $7.41-8.04(\mathrm{~m}, 10 \mathrm{H})$. ESI-MS (Positive mode); $m / z=321[\mathrm{M}+\mathrm{Na}]^{+}$and $[\alpha]_{\mathrm{D}}=-68.9\left(c 1.0, \mathrm{CHCl}_{3}\right)$. Spectroscopic data for characterization can be found in reference [10].

Supplementary Materials: The following are available online at http:/ /www.mdpi.com/1422-8599/2016/3/M905.

Acknowledgments: This research was supported in part by a grant from the College of Bioresource Sciences, Nihon University.

Author Contributions: S.I., R.O., and R.S. optimized the synthesis reaction of compound 1. K.G. optimized the reaction, acquired the spectra, and analyzed the data of compounds 3 and $3 R$. A.I. and S.Y. performed the HPLC analysis of compounds $3 R$ and $3 S$. W.H., T.H. and T.N. designed the synthesis reactions, confirmed the data analysis, and wrote the paper. All of the authors read and approved the final manuscript.

Conflicts of Interest: The authors declare no conflict of interest.

\section{References}

1. Scarlat, N.; Dallemand, J.F.; Monforti-Ferrario, F.; Nita, V. The role of biomass and bioenergy in future bioeconomy: Policies and facts. Environ. Dev. 2015, 15, 3-34. [CrossRef]

2. Cheali, P.; Quaglia, A.; Gernaey, K.V.; Sin, G. Effect of market price uncertainties on the design of optimal biorefinery systems-A systematic approach. Ind. Eng. Chem. Res. 2014, 53, 6021-6032. [CrossRef]

3. Bozell, J.J.; Petersen, G.R. Cutting-edge research for a greener sustainable future Technology development for the production of biobased products from biorefinery carbohydrates-The US Department of Energy's “Top 10" revisited. Green Chem. 2010, 12, 539-554. [CrossRef]

4. Long, X.; Ji, X. A review of the ecological and socioeconomic effects of biofuel and energy policy recommendations. Renew. Sustain. Energy Rev. 2016, 61, 41-52.

5. Wang, K.; Ou, L.; Brown, T.; Brown, R.C. Beyond ethanol: A techno-economic analysis of an integrated corn biorefinery for the production of hydrocarbon fuels and chemicals. Biofuels Bioprod. Biorefin. 2014, 16, 177-189. [CrossRef] 
6. George, A.; Brandt, A.; Tran, K.; Zahavi, S.M.N.S.; Klein-Marcuschamer, D.; Sun, N.; Sathitsuksanoh, N.; Shi, J.; Stavila, V.; Parthasarathi, R.; et al. Design of low-cost ionic liquids for lignocellulosic biomass pretreatment. Green Chem. 2015, 17, 1728-1734. [CrossRef]

7. Kataoka, N.; Vangnai, A.S.; Ueda, H.; Tajima, T.; Nakashimada, Y.; Kato, J. Enhancement of (R)-1, 3-butanediol production by engineered Escherichia coli using a bioreactor system with strict regulation of overall oxygen transfer coefficient and pH. Biosci. Biotechnol. Biochem. 2014, 78, 695-700. [CrossRef] [PubMed]

8. Matsuyama, A.; Yamamoto, H.; Kawada, N.; Kobayashi, Y. Industrial production of (R)-1,3-butanediol by new biocatalysts. J. Mol. Catal. B Enzym. 2001, 11, 513-521. [CrossRef]

9. Liu, Q.; Xu, G.; Wang, X.; Mu, X. Selective upgrading of ethanol with methanol in water for the production of improved biofuel-Isobutanol. Green Chem. 2016, 18, 2811-2818. [CrossRef]

10. Kim, S.M.; Kim, Y.S.; Kim, D.W.; Rios, R.; Yang, J.W. Acetaldehyde: A small organic molecule with big impact on organocatalytic reactions. Chem. Eur. J. 2016, 22, 2214-2234. [CrossRef] [PubMed]

11. Kumar, M.; Kumar, A.; Rizvi, M.A.; Shah, B.A. Acetaldehyde in asymmetric organocatalytic transformations. RSC Adv. 2015, 5, 55926-55937. [CrossRef]

12. Hayashi, Y.; Samanta, S.; Itoh, T.; Ishikawa, H. Asymmetric, catalytic, and direct self-aldol reaction of acetaldehyde catalyzed by diarylprolinol. Org. Lett. 2008, 10, 5581-5583. [CrossRef] [PubMed]

13. Córdova, A.; Notz, W.; Barbas, C.F., III. Proline-catalyzed one-step asymmetric synthesis of 5-hydroxy-(2E)-hexenal from acetaldehyde. J. Org. Chem. 2002, 67, 301-303. [CrossRef] [PubMed]

(C) 2016 by the authors; licensee MDPI, Basel, Switzerland. This article is an open access article distributed under the terms and conditions of the Creative Commons Attribution (CC-BY) license (http://creativecommons.org/licenses/by/4.0/). 